\title{
Penentuan Daerah Rawan Kecelakaan Lalu Lintas di Kota Surabaya
}

\author{
Vrischa Natalia Arung, ${ }^{1}$, Hera Widyastuti ${ }^{1, *}$ \\ Departement Teknik Sipil, Institut Teknologi Sepuluh Nopember, Surabaya ${ }^{1}$ \\ Koresponden*, Email: hera.widyastuti@yahoo.co.uk
}

\begin{tabular}{|c|c|c|}
\hline \multicolumn{2}{|c|}{ Info Artikel } & Abstract \\
\hline Diajukan & 1 Juli 2019 & Surabaya City as the Capital of East Java Province is the center of government activities, \\
\hline Diperbaiki & 31 Juli 2019 & besides that it is also one of the cities of trade, industry and education. This situation causes \\
\hline Disetujui & 2 Agustus 2019 & $\begin{array}{l}\text { community activities in the city of Surabaya to be quite high, giving rise to transportation } \\
\text { activities that have an impact on the increasing number of traffic growth. One of the effects of } \\
\text { traffic growth is the problem of accidents. During } 2016 \text { there were } 1.126 \text { traffic accidents in } \\
\text { the city of Surabaya, while in } 2017 \text { there were } 1.349 \text { accidents which resulted in } 174 \text { deaths. In } \\
\text { this study, for determine accident-prone areas (black sites) with the Z-Score method. The }\end{array}$ \\
\hline $\begin{array}{l}\text { Keywords: } 1 \\
\text { Score }\end{array}$ & black site, Z- & $\begin{array}{l}\text { results of this study, } 3 \text { (three) roads were designated as black sites in the city of Surabaya, } \\
\text { namely Ahmad Yani street, Mastrip street, and Ir. Soekarno street. }\end{array}$ \\
\hline
\end{tabular}

\begin{abstract}
Abstrak
Kota Surabaya sebagai Ibukota Provinsi Jawa Timur menjadi pusat kegiatan pemerintahan, selain itu juga sebagai salah satu kota perdagangan, industri, serta pendidikan. Keadaan ini menyebabkan kegiatan masyarakat di Kota Surabaya cukup tinggi, sehingga menimbulkan kegiatan transportasi yang berdampak pada meningkatnya angka pertumbuhan lalu lintas. Salah satu dampak dari pertumbuhan lalu lintas adalah masalah kecelakaan lalu lintas. Selama tahun 2016 tercatat 1.126 kejadian kecelakaan lalu lintas di Kota Surabaya, sedangkan pada tahun 2017 tercatat 1.349 kejadian kecelakaan yang mengakibatkan 174 orang meninggal dunia. Pada penelitian ini digunakan metode $Z$ Score untuk menentukan daerah rawan kecelakaan (black site), sehingga diperoleh 3 (tiga) ruas jalan yang ditetapkan sebagai black site di Kota Surabaya, yaitu Jalan Ahmad Yani, Jalan Mastrip, dan Jalan Ir. Soekarno.
\end{abstract}

Kata kunci: kecelakaan lalu lintas, black

\section{Pendahuluan}

Kota Surabaya sebagai Ibukota Provinsi Jawa Timur menjadi pusat kegiatan pemerintahan, selain itu juga sebagai salah satu kota perdagangan, industri, serta pendidikan[1]. Kegiatan ini berdampak pada meningkatnya volume kendaraan di Kota Surabaya[2]. Salah satu dampak dari meningkatnya volume lalu lintas adalah masalah kecelakaan lalu lintas. Selama tahun 2016 tercatat 1.126 kejadian kecelakaan lalu lintas di Kota Surabaya, sedangkan pada tahun 2017 tercatat 1.349 kejadian kecelakaan yang mengakibatkan 174 orang meninggal dunia [3].

Faktor penyebab kecelakaan lalu lintas adalah kondisi lalu lintas yang merupakan akumulasi interaksi dari berbagai karakteristik pengemudi, kendaraan, prasarana jalan maupun karakteristik lingkungan[4]. Meningkatnya volume lalu lintas, jalan yang lebih panjang, jumlah titik akses per kilometer dan meningkatnya kecepatan lalu lintas akan menyebabkan meningkatnya risiko kecelakaan lalu lintas di jalan arteri[5]. Kendaraan yang terlibat dalam kecelakaan lalu lintas dengan jumlah tertinggi di Kota Surabaya adalah sepeda motor[6]. Dari data kecelakaan lalu lintas di Kota Surabaya pada tahun 2017, jumlah sepeda motor yang terlibat kecelakaan lalu lintas adalah sebanyak 1.811 kendaraan dari total 2.327 kendaraan yang terlibat[3]. Profesi dari pelaku kecelakaan dengan jumlah tertinggi adalah karyawan, pelajar dan mahasiswa, yang berarti rentang usia pelaku kecelakaan berada dalam usia produktif [3],[6],[7].

Oleh karena itu, dilakukan analisis kecelakaan lalu lintas pada ruas jalan di Kota Surabaya untuk mengetahui dimana letak daerah rawan kecelakaan (black site), sehingga dapat segera dilakukan penanganan. Pada penelitian ini, untuk menentukan dimana letak daerah rawan kecelakaan (black site) digunakan metode Z-Score[8].

\section{Metode Penelitian}

Pengumpulan Data

Tahap awal dari penelitian ini adalah mengumpulkan data sekunder berupa data kecelakaan lalu lintas dari Kepolisian Resort Kota Surabaya, data yang diperoleh mencakup jumlah kecelakaan, jumlah korban berdasarkan fatalitas dan kerugian materil, serta data karakteristik kecelakaan[3]. Data kecelakaan lalu lintas yang dikumpulkan merupakan data selama kurun waktu 5 (lima) tahun, yaitu mulai tahun 2013 hingga tahun 2017. Data ruas jalan diperoleh dari Dinas Pekerjaan Umum Kota Surabaya yang berupa data status, fungsi, dan panjang jalan[9].

\section{Analisis Data}

Tahap analisis data diawali dengan mengelompokkan data kecelakaan setiap tahun pada masing-masing ruas jalan, 
kemudian membobotkan dan mengakumulasikan jumlah korban kecelakaan berdasarkan fatalitas serta kerugian materil. Melakukan uji statistik kendali mutu untuk menentukan ruas jalan mana saja yang merupakan daerah rawan kecelakaan. Selanjutnya melakukan uji Z-Score untuk menentukan ruas jalan yang memiliki angka kecelakaan tertinggi, sehingga dapat ditentukan sebagai daerah rawan kecelakaan (black site).

\section{Pembobotan Kecelakaan Lalu Lintas}

Pembobotan kecelakaan lalu lintas dilakukan dengan metode Angka Ekivalen Kecelakaan/ Equivalent Accident Number (EAN) berdasarkan nilai pembobotan terhadap jumlah korban meninggal, luka berat dan luka ringan, serta besar kerugian materil pada setiap ruas jalan. Nilai bobot standar yang digunakan mengacu pada biaya kecelakaan dengan nilai pembobotan sebagai berikut[8],[10]:

MD : LB : LR : $\mathrm{K}=12: 3: 3: 1$

Dimana:

$\mathrm{MD}=$ Meninggal dunia

LB = Luka berat

LR = Luka ringan

$\mathrm{K}=$ Kecelakaan dengan kerugian materi

\section{Statistik Kendali Mutu}

Statistik kendali mutu digunakan sebagai salah satu metode untuk menentukan lokasi daerah rawan kecelakaan (black site). Statistik kendali mutu adalah nilai batas yang dapat dihitung antara lain dengan menggunakan metode Batas Kontrol Atas (BKA) dan Upper Control Limit (UCL) [8],[11]. Jika suatu segmen ruas jalan memiliki nilai tingkat kecelakaan lalu lintas berada di atas garis BKA dan UCL, maka segmen ruas jalan tersebut diidentifikasi sebagai lokasi rawan kecelakaan lalu lintas[8].

Nilai Batas Kontrol Atas (BKA) ditentukan dengan menggunakan persamaan berikut:

$\mathrm{BKA}=C+3 \sqrt{C}$

Dimana :

$$
\mathrm{C}=\text { Rata-rata angka kecelakaan EAN }
$$

Nilai UCL (Upper Control Limit) ditentukan dengan menggunakan persamaan berikut:

$\mathrm{UCL}=\lambda+\psi \sqrt{\frac{\lambda}{m}}+\frac{0.829}{m}+\frac{1}{2 m}$

Dimana:

$$
\begin{array}{ll}
\lambda & =\text { Rata-rata angka kecelakaan EAN } \\
\Psi & =\text { Faktor probabilitas }=2.576 \\
\mathrm{~m} & =\text { Angka kecelakaan ruas yang ditinjau (EAN) }
\end{array}
$$

Nilai faktor probabilitas $(\Psi)$ ditentukan oleh probabilitas bahwa tingkat kecelakaan cukup besar sehingga kecelakaan tidak dapat dianggap sebagai kejadian acak. Nilai faktor probabilitas $(\Psi)$ yang sering digunakan seperti terlihat pada Tabel 1 yaitu 2,576 dengan probabilitas 0,005 (atau nilai signifikansi 99,5\%) dan 1,645 dengan probabilitas 0,05 (atau nilai signifikansi 95\%) [12],[13].
Tabel 1. Nilai Faktor Probabilitas

\begin{tabular}{cccccc}
\hline Probabilitas & 0,005 & 0,0075 & 0,05 & 0,075 & 0,10 \\
\hline$\Psi$ & 2,576 & 1,96 & 1,645 & 1,44 & 1,282 \\
\hline
\end{tabular}

Sumber : Khisty and Kent, 2003

Z-Score

Selain metode statistik kendali mutu, pada penelitian ini metode Z-Score digunakan untuk menentukan lokasi daerah rawan kecelakaan (black site). Nilai "z" dapat dikatakan seberapa standar deviasi jauh jarak nilai suatu data dengan nilai meannya (Hasan, 2001). Nilai " $z$ " dapat dicari dengan rumus[10]:

$\mathrm{Zi}=\frac{X i-\bar{X}}{S}$

Dimana :

$\mathrm{Zi}=$ Nilai Z-Score kecelakaan pada lokasi "i”

$\mathrm{S}=$ Standar Deviasi

$\mathrm{Xi}=$ Jumlah data pada lokasi "i"

$\overline{\mathrm{X}}=$ Nilai rata-rata

$\mathrm{i}=1,2,3, \ldots, \mathrm{n}$

Dalam perhitungan pertumbuhan indeks kecelakaan akan mencari nilai rata-rata dengan rumus[10]:

$\overline{\mathrm{X}}=\frac{\sum X}{n}$

Dimana :

$\overline{\mathrm{X}}=$ Nilai rata-rata

$\Sigma \mathrm{X}=$ Jumlah data

$\mathrm{N}=$ Jumlah sampel

Standar deviasi adalah ukuran yang menyatakan seberapa jauh penyimpangan nilai-nilai data dan nilai-nilai pusatnya. Standar deviasi untuk sampel besar $(n>30)$ dapat ditentukan dengan metode sebagai berikut[10]:

$\mathrm{S}=\sqrt{\frac{\sum(X-\bar{X})^{2}}{n}}$

Dimana :

$\partial \quad=$ Varians

$\mathrm{S}=$ Standar deviasi

$\mathrm{X}=$ Data

$\overline{\mathrm{X}}=$ Nilai rata-rata

$\mathrm{N}=$ Jumlah data

Setelah memperoleh nilai Z-Score dilakukan analisis menggunakan grafik kuadran. Analisis ini memiliki tujuan untuk mengukur hubungan antara 2 (dua) variabel[14]. Pada penelitian ini, variabel yang ingin diukur adalah Z-Score angka kecelakaan lalu lintas pada tahun 2017 dan Z-Score pertumbuhan angka kecelakaan lalu lintas selama 5 tahun. Grafik analisis kuadran Z-Score kecelakaan lalu lintas pada tahun 2017 dan Z-Score pertumbuhan kecelakaan lalu lintas selama 5 tahun dapat dilihat pada Gambar 1. 


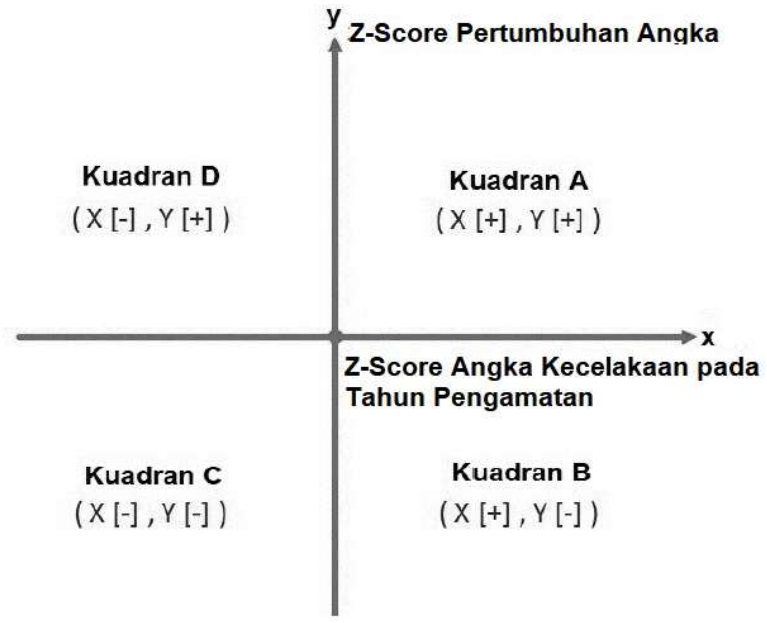

Gambar 1. Grafik Hubungan antara Z-Score Angka Kecelakaan Tahun Pengamatan dengan Z-Score Pertumbuhan Angka Kecelakaan

Keterangan :

- Kuadran $\mathrm{A}=$ Kuadran dengan angka kecelakaan tinggi dan pertumbuhan di atas nilai rata-rata angka kecelakaan di seluruh ruas jalan yang ditinjau pada Kota Surabaya.

- Kuadran B = Kuadran dengan angka kecelakaan tinggi dan pertumbuhan di bawah nilai rata-rata angka kecelakaan di seluruh ruas jalan yang ditinjau pada Kota Surabaya.

- Kuadran $\mathrm{C}=$ Kuadran dengan angka kecelakaan rendah dan pertumbuhan di bawah nilai rata-rata angka kecelakaan di seluruh ruas jalan yang ditinjau pada Kota Surabaya.

- Kuadran $\mathrm{D}=$ Kuadran dengan angka kecelakaan rendah dan pertumbuhan di atas nilai rata-rata angka kecelakaan di seluruh ruas jalan yang ditinjau pada Kota Surabaya.

\section{Hasil dan Pembahasan}

Pembobotan Kecelakaan Lalu Lintas

Pada penelitian ini dilakukan pembobotan terhadap jumlah korban meninggal, luka berat dan luka ringan, serta besar kerugian materil pada 554 ruas jalan di Kota Surabaya. Pada Tabel 3 dan Gambar 2 ditampilkan hasil perhitungan Angka Ekivalen Kecelakaan/Equivalent Accident Number (EAN) pada 20 ruas jalan di Kota Surabaya yang dibandingkan dengan nilai Batas Kontrol Atas (BKA) dan Upper Control Limit (UCL).

Hasil perhitungan Angka Ekivalen Kecelakaan pada 554 ruas jalan adalah ruas jalan yang memiliki nilai Angka Ekivalen Kecelakaan lebih tinggi dibandingkan nilai BKA adalah sebanyak 58 ruas jalan, sedangkan ruas jalan yang memiliki nilai Angka Ekivalen Kecelakaan lebih tinggi dibandingkan nilai BKA adalah sebanyak 87 ruas jalan.

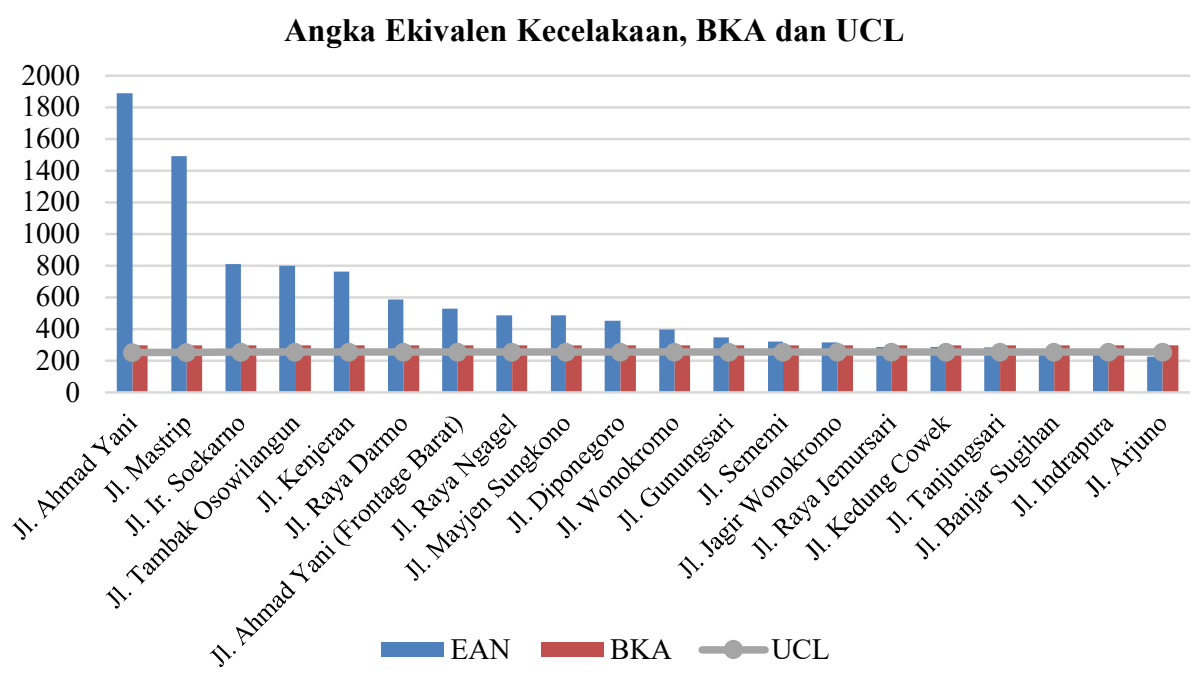

Gambar 2. Ekivalen Angka Kecelakaan BKA dan UCL 
Jika suatu segmen ruas jalan memiliki nilai Ekivalen Angka Kecelakaan lalu lintas berada di atas nilai BKA atau UCL, maka segmen ruas jalan tersebut dapat diidentifikasi sebagai daerah rawan kecelakaan lalu lintas.

Dari Gambar 2 dapat diketahui bahwa 10 ruas jalan yang memiliki angka ekivalen kecelakaan tertinggi adalah Jalan Ahmad Yani, Jalan Mastrip, Jalan Ir. Soekarno, Jalan Tambak Osowilangun, Jalan Kenjeran, Jalan Raya Darmo, Jalan Ahmad Yani (Frontage Barat), Jalan Raya Ngagel, Jalan Mayjen Sungkono, dan Jalan Diponegoro berada di atas nilai BKA atau UCL.

\section{Daerah Rawan Kecelakaan (Black Site)}

Metode yang digunakan untuk menentukan Daerah Rawan Kecelakaan (black site) adalah metode Z-Score. Nilai Z-Score (Zi) angka kecelakaan lalu lintas selama 5 tahun pada ruas jalan Ahmad Yani adalah sebesar 13,76. Nilai $Z$ Score tersebut diperoleh dari angka kecelakaan lalu lintas selama 5 tahun yang dibobotkan dan dikurangi rata-rata angka kecelakaan $(\overline{\mathrm{X}})$ sebesar 50,44, kemudian dibagi dengan nilai standar deviasi (S) sebesar 133,59.

Nilai Z-Score (Zi) angka kecelakaan lalu lintas tahun 2017 pada ruas jalan Ahmad Yani adalah sebesar 12,55. Nilai $Z$-Score tersebut diperoleh dari angka kecelakaan lalu lintas tahun 2017 yang dibobotkan dan dikurangi rata-rata angka kecelakaan $(\overline{\mathrm{X}})$ sebesar 12,27 , kemudian dibagi dengan nilai standar deviasi (S) sebesar 35,90.

Z-Score selama kurun waktu 5 (lima) tahun dan Z-Score tahun 2017 dibuat ke dalam bentuk tabel kemudian dilakukan pengujian untuk menentukan ruas jalan yang merupakan black site di Kota Surabaya. Pada Tabel 2 dapat dilihat 10 dari 554 ruas jalan yang memiliki nilai $Z$-Score tertinggi.
Tabel 2. Hasil Perhitungan Z-Score Angka Kecelakaan pada Ruas Jalan di Kota Surabaya dengan Hasil Z-Score Tertinggi

\begin{tabular}{clrr}
\hline No. & \multicolumn{1}{c}{ Nama Jalan } & $\begin{array}{c}\text { Z-Score } \\
\text { Tahun } \\
2017\end{array}$ & $\begin{array}{c}\text { Z-Score } \\
\text { 5 Tahun }\end{array}$ \\
\hline 1 & Jl. Ahmad Yani & 12.55 & 13.76 \\
2 & Jl. Mastrip & 8.74 & 10.79 \\
3 & Jl. Ir. Soekarno & 6.87 & 5.69 \\
4 & Jl. Tambak Osowilangun & 2.72 & 5.62 \\
5 & Jl. Kenjeran & 3.47 & 5.35 \\
6 & Jl. Raya Darmo & 2.25 & 4.02 \\
7 & Jl. Ahmad Yani (F. Barat) & 11.22 & 3.59 \\
8 & Jl. Raya Ngagel & 3.50 & 3.28 \\
9 & Jl. Mayjen Sungkono & 2.55 & 3.26 \\
10 & Jl. Diponegoro & 3.00 & 3.01 \\
\hline
\end{tabular}

Daerah rawan kecelakaan (black site) ditentukan dengan membuat sebuah grafik antara Z-Score pertumbuhan angka kecelakaan lalu lintas pada ruas-ruas jalan Kota Surabaya sejak tahun 2013 hingga tahun 2017 dengan Z-Score angka kecelakaan lalu lintas pada ruas-ruas jalan di Kota Surabaya pada tahun 2017. Kemudian pada grafik tersebut dapat dilihat ruas jalan mana saja yang menjadi black site.

Grafik black site pada 10 ruas jalan dengan nilai Z-Score pertumbuhan dan nilai Z-Score pada tahun 2017 tertinggi dapat dilihat pada Gambar 3. Ruas-ruas jalan yang berada pada kuadran A atau ruas-ruas jalan yang memiliki angka pertumbuhan kecelakaan lalu lintas dan angka kecelakaan lalu lintas tertinggi pada tahun 2017 dapat diidentifikasi sebagai daerah rawan kecelakaan (black site).

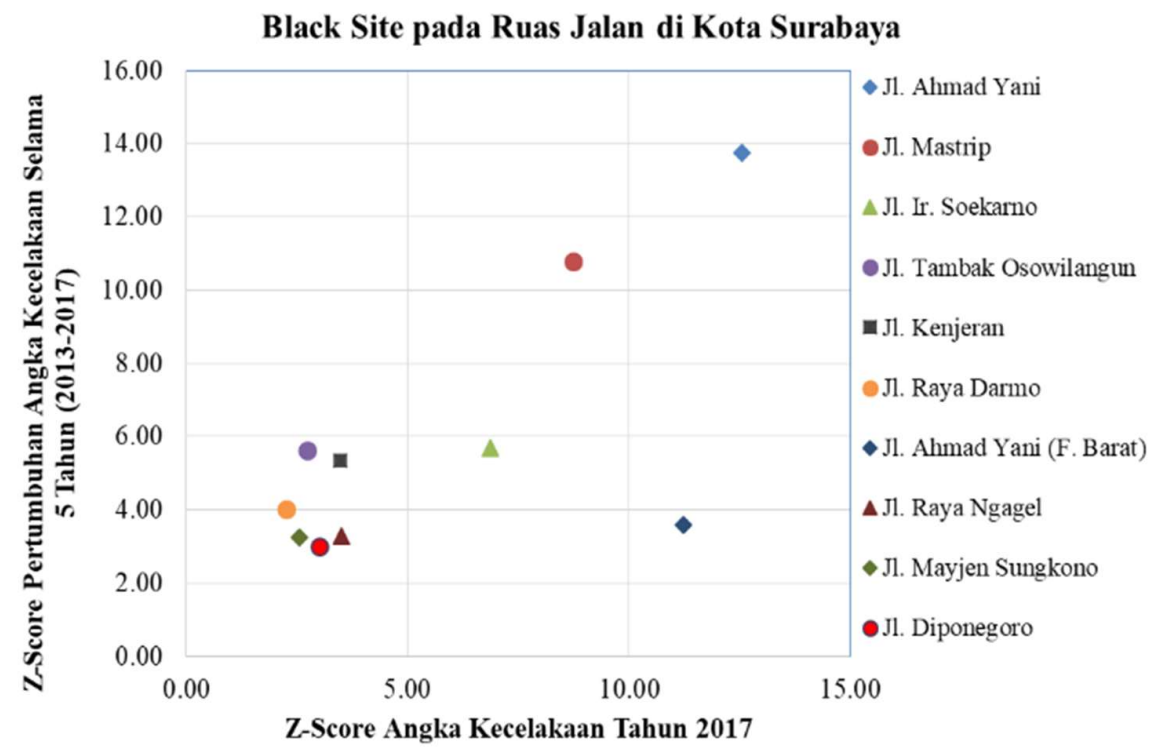

Gambar 3. Black Site pada Ruas Jalan di Kota Surabaya 
Dari Gambar 3 diperoleh 3 (tiga) ruas jalan yang memiliki Z-Score angka kecelakaan lalu lintas tertinggi atau yang terletak pada kuadran A yaitu ruas Jalan Ahmad Yani, Jalan Mastrip dan Jalan Ir. Soekarno.

Dari Tabel 2 dan Gambar 3 diketahui bahwa Jalan Ahmad Yani ditetapkan sebagai black site ruas jalan di Kota Surabaya dengan nilai Z-Score tertinggi memiliki nilai $Z$ Score tahun 2017 sebesar 12,55 dan Z-Score selama 5 tahun sebesar 13,76. Deskripsi kondisi ruas Jalan Ahmad Yani adalah sebagai berikut:

a. Ruas Jalan Ahmad Yani merupakan jalan yang tergolong sebagai jalan arteri primer dan memiliki tipe 6/2D yang berarti jalan tersebut memiliki 6 lajur dengan 2 jalur terpisah oleh median. Median memiliki lebar rata-rata 1,0 meter.

b. Jalan Ahmad Yani memiliki panjang 4,68 $\mathrm{km}$ dengan lebar rata-rata setiap lajur sebesar 3,5 meter. Kondisi jalan yang cukup panjang dan lebar seringkali menyebabkan pengendara terdorong untuk memacu kendaraannya di atas batas kecepatan yang diizinkan.

c. Terdapat frontage road pada sisi timur dan barat Jalan Ahmad Yani.

d. Kecepatan rata-rata kendaraan pada ruas Jalan Ahmad Yani berdasarkan survei kecepatan adalah sebesar 30,27 $\mathrm{km} / \mathrm{jam}$.

e. Kondisi permukaan jalan cenderung lurus dengan perkerasaan aspal, dan kondisi permukaan rata. Kondisi ini juga seringkali membuat pegendara lengah, sehingga perlu dipasang speed trap pada titik tertentu untuk meningkatkan kewaspadaan pengendara.

f. Tata guna lahan di sekitar jalan Ahmad Yani adalah perkantoran, pertokoan/pusat perbelanjaan, kawasan pendidikan, dan rumah sakit.

g. Dibeberapa titik terdapat zebra cross yang dilengkapi pelican crossing traffic light dan speed trap yang berguna untuk memberi peringatan bagi pengemudi untuk berhatihati dan mengurangi kecepatan. Selain zebra cross, pada jalan Ahmad Yani juga terdapat jembatan penyeberangan yang berada di depan kantor Dinas Pertanian dan Ketahanan Pangan Provinsi Jawa Timur.

Pada ruas jalan Ahmad Yani juga terdapat frontage road sisi Barat dan Timur. Dari penelitian yang dilakukan oleh Machsus et al (2017), kecelakaan lalu lintas sering terjadi pada frontage road khususnya pada frontage road sisi Barat yang diakibatkan oleh pelanggaran batas kecepatan maksimum. Kondisi geometris frontage road Jalan Ahmad Yani cenderung datar dengan lebar jalan rata-rata 15 meter, alasan ini mendorong pengendara untuk berkendara dengan kecepatan tinggi [15].

Dari Tabel 2 dan Gambar 3 diketahui bahwa Jalan Mastrip ditetapkan sebagai black site ruas jalan di Kota Surabaya dengan nilai $Z$-Score tertinggi kedua yang memiliki nilai Z-Score tahun 2017 sebesar 8,74 dan Z-Score selama 5 tahun sebesar 10,79. Deskripsi kondisi ruas Jalan Mastrip adalah sebagai berikut: a. Ruas Jalan Mastrip merupakan jalan yang tergolong sebagai jalan kolektor primer dan memiliki 2 tipe jalan yaitu 4/2 UD dan 2/2 UD. Sepanjang jalan tidak memiliki median, hanya terdapat marka lurus pengganti median. Hal ini yang menyebabkan pengemudi sering menggunakan jalur dari arah berlawanan untuk menyalip.

b. Jalan Mastrip memiliki panjang $7.77 \mathrm{~km}$ dengan lebar rata-rata setiap lajur sebesar 3,25 hingga 3,50 meter. Kondisi jalan yang cukup panjang dan lebar seringkali menyebabkan pengendara terdorong untuk memacu kendaraannya di atas batas kecepatan yang diizinkan.

c. Lebar rata-rata bahu jalan adalah sebesar 0,5 hingga 1,0 meter.

d. Kondisi permukaan jalan cenderung lurus dengan perkerasaan aspal, namun pada beberapa bagian jalan kondisi permukaan bergelombang dan berlubang. Kondisi jalan yang berlubang apabila tidak segera ditangani dapat membahayakan pengguna jalan.

e. Kecepatan rata-rata kendaraan pada ruas Jalan Ahmad Yani berdasarkan survei kecepatan adalah sebesar 29,86 $\mathrm{km} / \mathrm{jam}$.

f. Tata guna lahan di sekitar jalan Mastrip adalah kawasan industri, perdagangan, dan pemukiman.

g. Terdapat cukup banyak rambu peringatan, namun rambu petunjuk kurang memadai dan posisi rambu banyak yang sulit terlihat akibat tertutup pohon/bangunan. Rambu peringatan lokasi rawan kecelakaan dengan ukuran yang cukup besar dan mudah terlihat oleh pengendara, seperti terdapat pada Gambar 5.5. Selain itu sebesar $65 \%$ marka jalan sudah terhapus/tidak nampak dengan jelas.

h. Dibeberapa titik terdapat zebra cross yang dilengkapi pelican crossing traffic light dan speed trap yang berguna untuk memberi peringatan bagi pengemudi untuk berhatihati dan mengurangi kecepatan. Selain zebra cross. Terdapat 7 (tujuh) zebra cross yg dilengkapi dengan PTC, yaitu terdapat pada Kedurus III Masjid, Puskesmas Kedurus, Bongangin I, Masjid Agung, Masjid Jami' Baitusallam, Masjid At-Taqwa, dan PT Suparma Tbk.

i. Umumnya sepeda motor dan kendaraan roda 4, serta truk besar pada jam-jam operasional khusus. Cukup banyak kendaraan yang parkir di pinggir jalan, khusunya kendaraan roda 4 dan truk. Kondisi ini dapat membahayakan pengendara karena sudut pandang yang terganggu, dan ruang gerak menjadi terbatas.

Dari Tabel 2 dan Gambar 3 diketahui bahwa Jalan Ir. Soekarno ditetapkan sebagai black site ruas jalan di Kota Surabaya dengan nilai Z-Score tertinggi ketiga yang memiliki nilai Z-Score tahun 2017 sebesar 6,87 dan Z-Score selama 5 tahun sebesar 5,69. Deskripsi kondisi ruas Jalan Ir. Soekarno adalah sebagai berikut :

a. Ruas Jalan Ir. Soekarno memiliki tipe $6 / 2$ D yang berarti jalan tersebut memiliki 6 lajur dengan 2 jalur terpisah oleh median. Median memiliki lebar rata-rata 1,0 meter.

b. Jalan Ir. Soekarno memiliki panjang 9,165 km dengan lebar rata-rata setiap lajur sebesar 3,5 meter. Kondisi jalan yang cukup panjang dan lebar seringkali menyebabkan 
pengendara terdorong untuk memacu kendaraannya di atas batas kecepatan yang diizinkan.

c. Kondisi permukaan jalan cenderung lurus dengan perkerasaan aspal, dan kondisi permukaan rata. Kondisi ini juga seringkali membuat pegendara lengah, sehingga perlu dipasang speed trap pada titik tertentu untuk meningkatkan kewaspadaan pengendara.

d. Rambu yang terpasang cukup banyak dan kondisi marka masih jelas terlihat.

e. Tata guna lahan di sekitar jalan Ir. Soekarno adalah perkantoran, pertokoan/pusat perbelanjaan, kawasan pendidikan, dan kawasan bisnis.

f. Sebagian besar ruas jalan Ir Soekarno dilengkapi dengan trotoar. Namun pada beberapa lokasi, trotoar tidak dapat difungsikan sebagai tempat bagi pejalan kaki karena ditumbuhi tanaman liar dan kondisi permukaannya tidak rata atau berlubang.

g. Kecepatan rata-rata kendaraan pada ruas Jalan Ahmad Yani berdasarkan survei kecepatan adalah sebesar 29,71 $\mathrm{km} / \mathrm{jam}$.

h. Dibeberapa titik terdapat zebra cross yang dilengkapi pelican crossing traffic light (PCTL) dan speed trap yang berguna untuk memberi peringatan bagi pengemudi untuk berhati-hati dan mengurangi kecepatan. Namun pada beberapa zebra cross tidak dilengkapi dengan PCTL dan sebagian zebra cross sudah tidak terlihat dengan jelas akibat overlay lapis aspal. Contohnya adalah zebra cross yang terdapat di depan SMP Negeri 19 Surabaya.

\section{Simpulan}

Berdasarkan hasil analisis dan pengolahan data yang dilakukan dengan menggunakan metode Z-Score, maka diambil kesimpulan bahwa daerah rawan kecelakaan (black site) pada ruas jalan di Kota Surabaya adalah sebagai berikut:

- Ruas jalan Ahmad Yani berada pada kuadran A dengan nilai Z-Score tahun 2017 sebesar 12,55 dan Z-Score selama 5 tahun sebesar 13,76.

- Ruas jalan Mastrip berada pada kuadran A dengan nilai Z-Score tahun 2017 sebesar 8,74 dan Z-Score selama 5 tahun sebesar 10,79.

- Ruas jalan Ir. Soekarno berada pada kuadran A dengan nilai $Z$-Score tertinggi ketiga yang memiliki nilai $Z$-Score tahun 2017 sebesar 6,87 dan Z-Score selama 5 tahun sebesar 5,69.

\section{Daftar Pustaka}

[1] Peraturan Daerah Provinsi Jawa Timur Nomor 5 Tahun 2012 "Rencana Tata Ruang Wilayah Provinsi Tahun 2011-2031.” 2012.

[2] A. Utami and H. Widyastuti, "Model Panjang Antrian Kendaraan pada Perlintasan Sebidang Tanpa Palang Pintu (Studi Kasus: Perlintasan Sebidang Jalan Gayung Kebonsari Surabaya )," Jurnal Aplikasi Teknik Sipil (JATS,) vol. 17, no. 23, pp. 27 34, 2019.
[3] Kepolisian Resort Kota Surabaya, 'Data Kecelakaan Lalu Lintas Kota Surabaya," 2017.

[4] I. G. . P. Adnya Swari, P. A. Suthanaya, and I. N. W. Negara, "Analisis Biaya Dan Penanganan Lokasi Rawan Kecelakaan Akibat Kecelakaan Lalu Lintas Di Kota Denpasar,' Jurnal. Spektran, vol. 2, pp. 2430, 2014.

[5] Machsus, H. Sulistio, A. Wicaksono, and L. Djakfar, "The Prediction Models of Motorcycle Accidents on Surabaya Arterial Roads Using Generalized Linear Models," Middle-East Journal of Scientific Research, vol. 18, no. 12, pp. 1859-1866, 2013.

[6] H. Widyastuti et al., "Evaluation of Responsible Riding Program on Reducing Number of Motorcycle Accident," Proceedings of the Eastern Asia Society for Transportation Studies, vol. 7, no. 1995, 2009.

[7] H. Widyastuti et al., "Evaluation of Indonesia Road Safety Campaigns (RUNK)," Procedia - Social. Behaviour Sci., vol. 227, pp. 530-535, 2016.

[8] Pusat Litbang Prasarana Transportasi, "Penanganan Lokasi Rawan Kecelakaan Lalu Lintas,” p. 54, 2004.

[9] "Dinas Pekerjaan Umum Kota Surabaya, 'Data Ruas Jalan Kota Surabaya," no. 1, 2017.

[10] I. D. A. Bagus, dan G. Laksmana, "Analisis Kecelakaan Lalu Lintas Studi Kasus Kota Denpasar," Jurnal Teknik Sipil, 2016.

[11] G. Sugiyanto, A. Fadli, and M. Y. Santi, "Identification of Black Spot and Equivalent Accident Number Using Upper Control Limit Method," ARPN Journal Eng. Appl. Sci., vol. 12, no. 2, pp. 528-535, 2017.

[12] G. Sugiyanto et al., "Metode Gross Output dari Departemen Permukiman dan Prasarana Wilayah," pp. 1-3, 2013.

[13] B. dan K. L. Jotin Khisty, Transportation Engineering, Edisi 3. Erlangga, 2003.

[14] D. R. Brandt, "An 'Outside-In'Approach to Determining Customer Driven Priorities for Improvement and Innovation," White Paper Ser., vol. 2, 2000.

[15] Machsus, I. Prayogo, Chomaedhi, D. W. Hayati, and A. Utanaka, "Road Safety Analysis on Achmad Yani Frontage Road Surabaya Road Safety Analysis on Achmad Yani Frontage Road Surabaya," IOP Conf. Series: Materials Science and Engineering 267, 2017. 